\section{Kastamonu Eğitim Dergisi Kastamonu Education Journal}

Eylül 2019 Cilt:27 Sayı:5

kefdergi.kastamonu.edu.tr
Başvuru Tarihi/Received: 18.12.2018

Kabul Tarihi/Accepted: 18.01.2019

DOI: 10.24106/kefdergi.3486

\title{
Öğrenci Görüşlerine Göre Coğrafya Öğretim Programındaki Bitki Coğrafyası Kazanımlarının Bitki Örtüsünü Tanımaya Etkisi' ${ }^{1}$
}

\section{The Effect of The Plant Geography Objectives in The Geography Curriculum on Recognizing Plants Based on Student Views}

\section{Öz}

\author{
Ziya iNCE
}

Bitkiler yer küredeki canlı hayatın devamlılığını sağlayan en önemli unsurlardan biridir. Ancak insanoğlunun doğal çevreden ve özellikle bitkilerden umursamaz bir şekilde faydalanması neticesinde bugün bu doğal kaynağın bazı bileşenleri yok olmuş bazıları ise yok olma tehlikesi ile karşı karşıyadır. Bu sebeple doğal çevrenin bir parçası olan bitki örtüsünü tanımak ve onu daha iyi incelemek insanların gözündeki değerini arttırmaktadır. Bu konuda ilk ve en önemli bilgiler insanlara ortaokul ve lise çağlarında coğrafya derslerinde verilmektedir. Bu açıdan coğrafya öğretim programındaki bitki örtüsü kazanımları ve bunların öğrenci zihninde oluşturduğu algı çok önemli bir yer oluşturmaktadır.

Bu çalışmanın amacı, coğrafya öğretim programındaki bitki coğrafyası kazanımlarının bitki örtüsünü tanımaya etkisini öğrenci görüşlerine göre fenomenolojik yöntem kullanarak incelemektir. Bitki coğrafyası konusu ile ilgili alanyazın taraması yapıııp ve uzman görüşü alındıktan sonra öğrencilerin bitki coğrafyası konusundaki bilgi seviyeleri hakkındaki görüşlerini almaya yönelik yarı yapılandırımış görüşme formu hazırlanmıştır. Araştırmanın evrenini ortaöğretim öğrencileri oluşturur iken, örneklemini İstanbul ili Bağcılar ilçesindeki Anadolu lisesi öğrenciler oluşturmaktadır. Araştırmaya 40 öğrenci katılmıştr.

Bu araştırma, bizlere öğrencilerin bitki örtüsü konusundaki düşüncelerinde coğrafya dersinin olumlu neticeler doğurduğunu göstermektedir. Coğrafya öğretmenlerinin şahsi gayret ve istekleri de bu olumlu gelişmede önemli bir paya sahiptir. Araştırmada elde edilen veriler incelendiğinde ortaöğretim öğrencilerinin bitkileri tanımada coğrafya öğretim programındaki kazanımların ve ders kitaplarının önemli olduğu sonucuna ulaşımıştır. Ayrıca öğrenciler çevrelerindeki bitkileri daha fazla tanımak için coğrafya dersi yanında diğer derslerde de bu konunun önemsenmesi gerektiği belirtmişlerdir.

Anahtar Kelimeler: Doğal çevre, coğrafya eğitimi, bitki coğrafyası, coğrafya öğretim programı

\section{Abstract}

Plants are one of the most important elements that ensures the continuity of life on Earth. However, as a result of humanity recklessly using the natural environment and especially plants, some components of this natural resource have been destroyed and some are facing the danger of extinction. This is why recognizing plant, which is one part of the natural environment, and better studying it increases its value in the eyes of people. People are provided with the primary and most important information on this issue in their middle school and high school geography courses. From this perspective, objectives for plant in the geography curriculum and the perception that these creates in the minds of students constitute a very important place.

The purpose of this study is to examine the effect of becoming familiar with the plant component of plant geography objectives in geography curriculum using phenomenological techniques based on the views of the students. After a review of the literature regarding the topic of plant geography is done and expert opinions are received, a semi-structured interview form was prepared with the goal of obtaining the students' levels of knowledge on the topic of plant geography. Secondary education students constitute the population of the study, while Anadolu High School students in the Bağclar district of the Istanbul province constitute the sampling. Forty students participated in the research.

This study shows us geography classes produce positive results in the thoughts of students on the topic of plant. The personal efforts and wishes of geography teachers have an important share in this positive development. When studying the data obtained in the study, it was concluded that the secondary education students' objectives and textbooks in the geography curriculum were important in recognizing the plants. The students also reported that this subject needed to be valued more in both geography classes and other classes in order to become familiar with more plants in the environment.

Keywords: Natural environment, geography education, plant geography, geography curriculum

1. ICTAG Conference 22-23th May 2015 Ankara'da sunulan özet bildirinin genişletilmiş halidir.

2. Namık Kemal Üniversitesi, Tekirdağ, Türkiye; Türkiye; https://orcid.org/0000-0001-7389-8083

Attf / Citation: İnce, Z. (2019). Öğrenci görüşlerine göre coğrafya öğretim programındaki bitki coğrafyası kazanımlarının bitki örtüsünü tanımaya etkisi. Kastamonu Education Journal, 27(5), 2279-2292. doi:10.24106/kefdergi.3486 


\section{Extended Abstract}

Introduction: Geography is a science that examines the mutual relationships between people and the geographic environment by establishing relationships between natural, human, and economic phenomena (Doğanay, 1993) (Doğanay, 2017, p. 103). We can describe the objective of geography in this situation as recognizing the spaces and environment in which people live, establishing good relationships, and ensuring harmony.

Many different sciences study the natural environment and especially plants. Geography is one of these branches of science, and it also studies plants and makes a bid for future generations to recognize plants. While studying natural environments, geography is separated into many sections, one of which is plant geography. According to Atayeter (265), plant geography is one of the many sub-branches of physical geography. Doğanay (1993) discussed plant geography within the definition of "biogeography", and stated that it is definitely not botanical science.

The plant geography objectives within the secondary education geography curriculum, the subject of our research, is transferred to the youth through geography education. Thus, people recognizing the plants in the spaces where they live will increase the value that they provide to them.

The fundamental purpose of this study is to examine to what degree the plant geography objectives in the secondary education geography curriculum are effective in students identifying plants. The main and sub-problems of the research can be listed as follows in this context:

Are there an adequate number of plant geography objectives in the secondary education geography curriculum?

Is there an effect of the plant geography objectives in the secondary education geography syllabus over students recognizing plants? If there is an effect, what level is this effect at?

Do the plant geography subjects that the students saw in their geography courses create curiosity, awareness, and consciousness on the topic of identifying those plants?

However, the plant geography objectives in the secondary education geography curriculum were not widespread in the program. This study is important in terms of being a roadmap for future studies.

Method: It was researched to what degree the plant geography objectives in the secondary education geography syllabus were effective in the students identifying plants in this study, which used a phenomenological design, a qualitative research method. The research was conducted over a working group composed of Anadolu High School students in the Bağcılar district of the Istanbul province in the 2014-2015 academic year. With the relationship of plant geography subjects being found only in the 10th grade program, those who would participate in the study were selected from 10th grade students. Of those who participated in the research, 23 were girls and 17 were boys.

An interview technique was used as a data-collection tool. On the interview form, students were asked eight short and open-pointed questions about plant geography. The response texts that the students provided were read from start to end, the word blocks and concepts were coded, and categories (themes) were created, setting out from the similarities and differences between the codes. Descriptive interpretations were made with regard to these codes and themes. The findings obtained from the questions were made visible by being process in tables.

Findings: Based on the purpose of the study, the sections related to plant geography were attempted to be discovered in the general objectives section of the geography course curriculum. Plant geography is among the important subjects of the Natural Systems unit in the 10th-grade section of the Geography curriculum. Students knowing, analyzing, and interpreting the properties, distribution, and cohesion with natural circumstances of the vegetation around the world and in Turkey are among the important goals of the program. However, in light of these data, the fact that plant geography is being given with only three objectives and the mention of only two objectives in the 11th- and 12th-grade programs in the explanations section indicates that little importance and time are set aside for this topic and that the objectives related to plant geography in the program are not adequate.

Eight open-ended questions were prepared for the second and third sub-problems of the research. It became necessary to separate the different responses, explanations, and multiple descriptive expressions that the students provided to the eight short and open-ended questions directed into categories such as "very little", "little", "sufficient", "good", and "very good" in order to better evaluate their responses. All of the responses to the questions were divided up into these categories. This is why sentences that resembled one another and that expressed similar meaning were combined and provided under the category frequency (f) total column in the tables.

More than half of the responses (57.5\%) that the students provided to one of the questions directed to the students, on the topic of the "pre-high school level of knowledge regarding plants", stated that their knowledge was "little" or "very little". According to these results, it was seen that the pre-high-school levels of knowledge about plants Anadolu High School 10th-grade students were low. The students were asked in which class they absorbed the most information while receiving their high school education, to which they named their geography, biology, literature, English, and drawing courses. The students who participated in the research stated that the plant geography topics they saw in their geography courses created a positive awareness and consciousness on the topic of identifying plants.

In light of the information obtained after introducing the topics of plant geography in geography courses, $72.5 \%$ (good and very good category) of students, when asked about their views of the plants around them and in the school garden stated that they wondered a lot about plants and that they even went in between the first class and counted these plants, particularly the trees. 
The categories of "considerable" was used rather than "good" in the categories in this question of whether the plant geography topics seen in the geography courses were adequate. A positive result emerged from the students in this question for the geography course.

In order for the students who participated in the research to be able to better understand the objectives related to the topic of plant geography, recommendations are made such as conducting trips in geography class, field work, bringing plant-identifying materials such as leaves to the classroom, making collections of leaves, preparing presentations related to trees, conducting interviews over trees with elderly people of the area, creating a photographic archive related to the topic, conducting or participating in tree-planting campaigns, watching documentaries related to plants, and writing poems related to trees.

Conclusion and Discussion : We conducted this study to determine to what degree the plant geography objectives in the secondary education geography curriculum are effective in students identifying plants, and it shows us that geography classes give rise to positive results over the students. The personal efforts and wishes of geography teachers have an important share in this positive development.

According to the findings from the research, it was seen that plant topics are not supported with field work for reasons like issues with time, issues with space, and crowded classrooms. It was concluded that many students were not aware about the plants around them. After the plant geography objectives, the students saw the formation distinction between the plants. For example, like how they learned not to call all needle-leafed tree a pine. Based on these data, the students have learned in their geography class that they set apart formations such as grass, bushes, and trees in defining the plants around them, that they grow under different climate conditions, and that the same plant species cannot be seen in every region because of factors such as climate, topography, soil characteristics, and water needs.

Students identifying plants in areas where greenspace has declined, and plants are no longer visible and showing them the relevance could only occur in academic institutions and, here, in geography courses. Recognizing the plants in the greenspaces at schools will help students, teachers, and parents both better protect and become more interested in those plants.

Plant geography is among the important courses in the geography undergraduate program for higher education. The fact that plant (vegetation) geography courses are taught throughout a term in the geography curricula for the Arts-Sciences Faculty and the Education Faculty in Turkey displays the prominence of the topic. However, the fact that the plant geography subjects that geography teacher candidates learn are explained with only three objectives in the secondary education geography curriculum indicates that adequate importance and time are not set aside for a topic this important. In this regard, it is recommended that more objectives be included for plant geography in the geography curriculum. 


\section{Giriş}

Coğrafya, insan ve coğrafi çevre arasındaki karşılıklı ilişkileri, doğal, beşeri ve ekonomik olguları insan ile ilgi kurarak inceleyen bir bilimdir (Doğanay, 1993; Doğanay, 2017, s. 103). Bir başka tanımla coğrafya, yeryüzünün tamamı veya bir parçası üzerinde, doğal, beşerî ve ekonomik olayların dağılışını, aralarındaki bağlantıları, sebep ve sonuçlarını inceleyen bir bilimdir (Özey, 2002). Bu durumda coğrafyanın amacını insanların yaşadıkları mekânları ve çevreyi tanıması, iyi ilişki kurması ve uyum sağlaması olarak tarif edebiliriz.

Doğal çevre, bilhassa bitkiler birçok farklı bilim tarafindan incelenmektedir. Biyoloji, botanik, coğrafya bunlardan bazılarıdır. Bu bilim dallarından biri olan coğrafya bilimi bitkileri incelemekte ve gelecek nesillerin bitkileri tanıması için uğraş vermektedir. Coğrafya doğal ortamları incelerken jeomorfoloji, klimatoloji hidrografya gibi birçok bölüme ayrılır. Atayeter'e (2013) göre bitki coğrafyası, fiziki coğrafyanın bu alt dalından bir tanesidir.

Dünyadaki canlı hayatın büyük bir bölümünü oluşturan, fotosentez ile üretim yaparak çeşitli tüketicilerin beslenmesini doğrudan sağlayan, enerji ve madde dolaşımında aktif rol oynayan ve dolayısıyla canlı hayatın vazgeçilmez unsurunu meydana getiren canlılar bitkilerdir (Atalay, 1992, s. 376). Yeryüzünde canlı hayatın devamının önemli bir parçası olan bitkiler Latincede flora ve vejetasyon terimleri ile ifade edilmiştir. Akman ve Ketenoğlu (1987), herhangi bir coğrafi bölgenin bir kesimi üzerinde yaşama şartları birbirine benzeyen bitkilerin bir arada toplanma şeklini vejetasyon olarak tarif etmiştir. Atalay, Türkiye Vejetasyon Coğrafyası adlı eserinde flora terimini şu şekilde tanımlamıştr: Herhangi bir sahada bulunan tüm bitkileri (yosun, ot, çalı, ağaç) olarak ifade etmektedir (Atalay, 1994, s. 1). Buna karşılık vejetasyon terimini ise; herhangi bir sahada bulunan bitkilerin ekolojik özellikleri ve fizyonomik görünümlerine göre orman, çalı, ot gibi topluluklara ayrılmasıdır (Atalay, 2013, s. 455) diye ifade etmiştir. Bitkilerin yetiştiği ve yeryüzünde dağılış alanlarını araştran bitki coğrafyası biyolojinin botanik kolundan yardım alır. Coğrafyanın biyoloji gibi birçok bilimden faydalanması bu bilime çok sayıda kavram ve terimin geçmesini kaçınılmaz kılmıştı. Coğrafyanın disiplinler arası bir bilim olmasının bu ilme kavram zenginliği kazandırdığı bir gerçektir (Alım, 2008)

Doğanay bitki coğrafyasını "biyocoğrafya" tanımı içinde ele almış ve kesinlikle botanik bilimi olmadığını ifade etmiştir (Doğanay, 1993, s. 441). Ayrıca Aydınözü ve Çoban (2015) bitki coğrafyasının botanik ilminden farklı olarak, daha çok bitki örtüsü formasyonları ve bunların yeryüzündeki dağılış düzenlerinin sebepleri üzerinde durduğunu ifade etmektedir.

Dünyada bilimsel ve teknolojik gelişmeler birçok yeniliği getirirken birçok doğal güzelliği de yok etmektedir. Örneğin küresel iklim değişimleri beraberinde kuraklık, sel, açlık ve kıtlık gibi felaketleri getirirken canlıları da etkilemektedir. Değişen iklim şartları beraberinde bitki örtüsünü ve canlıları etkilemekte, bunlardan bazılarının varlığı tehdit altına girmektedir (Şahin, 2015).

Insanların yaşama, çalışma, sanayi, ticaret, spor, eğitim, dinlenme ve eğlenme alanlarındaki yeşil alanların oranı giderek azalmaktadır. Turnaya göre Türkiye'de kişi başına düşen yeşil alan miktarı 1 ile $9 \mathrm{~m}^{2}$ arasında değişmekte ve bu miktar özellikle büyük şehirlerde hızla azalmaktadır (Turna, 2017). Yeşil alanların azaldığı, bitkilerin arttk görünmez olduğu yaşam alanlarında, öğrencilerin bitkileri tanımaları, onlara alaka göstermeleri ancak eğitim kurumlarında ve burada da coğrafya dersinde olabilmektedir.

Günümüz eğitim sisteminde bitki örtüsü konuları coğrafya ve biyoloji derslerinin müfredatında yer almaktadır. Ancak bu tam anlamı ile yeterli bir durum değildir. Bir çocuğun olumlu kimlik gelişimi, eleştirel düşünme ve problem çözme becerilerinin ortaya çıkması, kendine güveni, özsaygısı, hatta sağlık ve olgunlaşma durumu doğal dünya ile etkili etkileşimine dayalıdır (Kellert, 2007). Bu açıdan doğal çevreyi ve bunun bir parçası bitkileri tanıması önemli bir konudur. Doğa üzerindeki baskının özellikle 70'li yıllarda ağırlaşması ile beraber dünya kamuoyunun çevreye karşı duyarlılı̆ı artmıştır. Çevre eğitiminin genel eğitim sistemi içerisinde özel bir eğitim alanı olarak gündeme gelmesi, çevre sorunlarına çözüm arayışlarının yoğunlaştı̆ı 1970’li yıllara denk gelmektedir (Bilgili \& Kocalar, 2014).

Türkiye'de çocuklar ilkokuldan başlayarak, ortaokul ve lisede coğrafya konuları ile karşılaşmaktadırlar. İlkokulda hayat bilgisi, ortaokulda sosyal bilgiler ve lisede nihayet coğrafya dersi adıyla aldıkları coğrafi bilgiler içinde bitki coğrafyası kazanımları önemli yer tutmaktadır.

Araştırmanın konusu olan ortaöğretim coğrafya öğretim programı içindeki bitki coğrafyası kazanımları coğrafya eğitimi ile gençlere aktarıır. Coğrafya eğitimi ile verilen bilgiler genç nesillerin çevrelerini daha iyi tanımalarını, çevrelerinde meydana gelen tabii ve beşerî olaylara ve sorunlara daha dikkatli bir gözle bakmasını ve çözüm yolları üretmesini sağlayacağı beklenmektedir. Ortaöğretim coğrafya dersi müfredatındaki kazanımlar sayesinde öğrencilerin yakın çevrelerini tanıması önemli olduğundan (Ince, 2015) bitkileri tanıması da beklenir. Milli Eğitim Bakanlığı Talim Terbiye Kurulu 
başkanlı̆ıının internet sitesinde yayımladığı coğrafya öğretim programına göre öğrencilerin bazı bilgi, beceri ve yeterlikleri kazanması gerekmektedir. Öğretim programları ve ders kitaplarının bu yapıda olmasını, Sezer ve Şanlı (2017), "devletlerin vatandaşlarının bu olguya ilişkin ne bilmesini istediğinin izdüşümü" şeklinde yorumlamıştır.

Ortaöğretim kurumlarında öğretim programları ve bu öğretim programlarına göre hazırlanan ders kitapları sayesinde, öğrencilerde istendik davranışların gerçekleşmesi beklenirken, coğrafyanın bitki coğrafyası konusundaki kazanımları sayesinde de çevredeki bitkilerin daha iyi bilinmesi amaçlanmaktadır. İnsanların yaşadığı alandaki bitkileri tanıması ona vereceği değeri de arttracaktır.

\section{Amaç ve Önem}

Bu çalışmada temel amaç ortaöğretim coğrafya müfredatındaki bitki coğrafyası kazanımlarının, öğrencilerin bitkileri tanımalarında ne derece etkili olduğunun incelenmesidir. Bu bağlamda araştırmanın ana ve alt problemleri şöyle sıralanabilir:

- Ortaöğretim coğrafya programındaki bitki coğrafyası konusu kazanımları yeterli sayıda mıdır?

- Ortaöğretim coğrafya müfredatındaki bitki coğrafyası kazanımlarının, öğrencilerin bitkileri tanımalarında etkisi var mıdır? Etkili ise bu etki hangi seviyededir?

- Öğrencilerin coğrafya dersinde gördüğü bitki coğrafyası konuları, onlarında bitkileri tanıma konusunda bir merak, farkındalık ve bilinç oluşturmakta mıdır?

Literatür taraması yaptığımızda çevremizdeki bitkilerin tanınması konusunda çalışmalar az da olsa bulunmaktadır. İlseven ve diğerlerinin (2017) yaptı̆̆ı "Eğitim yöneticileri ve öğretmenlerin bitki örtüsü coğrafyasına ilişkin görüşleri" konulu çalışma, Geçit'in (2010) yaptiğı "Coğrafya eğitimi alanında temel yönelimler", Özbaş'ın (2013) yaptiğı "Ortaokul öğrencilerinin ormana yönelik tutumları: Lefkoşa örneği", Frost'un (2000) "Kuzey-Merkez Florida ve Peru-Amazon'da genç yetişkinler arasındaki ormanlara ilişkin tutumları" hakkındaki çalışması, Genç ve diğerlerinin (2010) "ilköğretim öğrencilerinin orman kavramını algılamaları" konulu çalışmaları ve Memişoğlu ve Öner'in (2013) yaptığı 'Sosyal bilgiler dersinde öğrenci ve öğretmen görüşlerine göre coğrafya konularının öğretimi' isimli çalışma bunlar arasında sayılabilir.

Ancak ortaöğretim coğrafya öğretim programında bitki coğrafyası kazanımları kendisine programda fazla yer bulamamıştır. Bu açıdan yapılan bu çalışma gelecekteki çalışmalar için yol gösterici olması bakımından daha önemli bir konuma gelmiştir.

\section{Sınırlılıklar}

Bu çalışma 2014-2015 eğitim-öğretim yılında İstanbul ili Bağcılar ilçesinde Anadolu lisesi öğrencileri ile yapılmıştır. Bitki coğrafyası konularının sadece 10.sınıf programında yer alması münasebeti ile çalışmaya katılacak öğrenciler 3 tane Anadolu lisesinin 10.sınıf öğrencileri ile sınırlı tutulmuştur.

\section{Yöntem:}

Ortaöğretim coğrafya müfredatındaki bitki coğrafyası kazanımlarının, öğrencilerin bitkileri tanımalarında ne derece etkili olduğunun araştrıldığı bu çalışmada nitel araştırma yöntemlerinden fenomenolojik desen kullanılmıştı. Fenomenolojik (Olgubilim) desen farkında olduğumuz ancak derinlemesine ve ayrıntılı bir anlayışa sahip olmadığımız olgulara odaklanmaktadır. Bize tümüyle yabancı olmayan aynı zamanda da tam anlamın kavrayamadığımız olguları araştırmayı amaçlayan çalışmalar için fenomenolojik desen uygun bir araştırma zemini oluşturur (Yıldırım \& Şimşek, 2013, s. 78). Fenomenografik araştırmalar fenomenin tecrübe edilme şekillerindeki temel farklıııklara odaklanır. Çalışmaların sonuçlarında bu farklılıkları ortaya koyan kavramsal kategoriler oluşturulur ve bu kategoriler birbirleriyle ilişkilendirilir (Çepni, 2014).

Araştırma sürecinin geçerlilik ve güvenirliğin sağlanması için; yapılan çalışmalar açık ve ayrıntılı bir şekilde yazılmış, verilerin analizi ve değerlendirilmesinde derinlemesine araştırma ve inceleme anlayışı benimsenerek sonuçların birbiriyle bağlantılı ve tutarlıı̆ına dikkat edilmiştir. Araştırmadan elde edilen verilere göre farklılıkları ortaya koyan kavramsal kategoriler oluşturulmuş ve birbirleriyle ilişkilendirilmeye çalışımıştır.

\section{Çalışma Grubu}

Fenomenolojik (Olgubilim) araştırmalarda veri kaynakları araştırmanın odaklandığı olguyu yaşayan ve bu olguyu dışa vurabilecek veya yansıtabilecek bireyler ya da gruplardır. Katılımcıların belirlenmesinde amaçlı örneklem seçimi tercih edilmiştir. Araştrma grubunun mümkün olduğu kadar farkı ilgi alanlarına ve başarı seviyelerine sahip öğrencilerden seçilmesine özen gösterilmiştir (Yıldııım \& Şimşek, 2013, s. 135). Araştırma 2014-2015 eğitim-öğretim yılında İstan- 
bul ili Bağcılar ilçesinde üç farklı Anadolu lisesi öğrencileri ile oluşan bir çalışma grubu üzerinden yürütülmüştür. Bitki coğrafyası konularının daha çok 10.sınıf programında yer alması münasebeti ile çalışmaya katllacak öğrenciler 10.sınıf öğrencilerinden ve bitki kazanımlarının işlenmiş olduğu sınıflardan seçilmiştir. Katılımcılar gönüllü bir şekilde araştırma sürecine katılmayı kabul etmiştir. Araştırmaya katılan öğrenci ve okul isimleri gizli tutulmuştur.

Tablo.01: Çalışma grubundaki öğrencilerin kişisel bilgileri

\begin{tabular}{lcc}
\hline Öğrencilerin Cinsiyete gör e dağılımı & $\mathbf{f}$ & \% \\
\hline Kız & 23 & 57,5 \\
Erkek & 17 & 42,5 \\
\hline Toplam & 40 & 100 \\
\hline
\end{tabular}

Araştırmaya katılanlar Tablo 1'de de görüldüğü üzere 23'ü kız, 17'i erkek öğrencilerden oluşmaktadır. Araştırma için görüşüne başvurulan öğrenci sayısı 48 iken araştırma sonunda verdikleri bilgilerde tutarsızlık görülen ve bazı sorulara cevap vermeyen adaylar araştırmaya dahil edilmemiş ve sayı 40 olarak netleşmiştir.

\section{Verilerin Toplanması}

Bu çalışmada, nitel araştırma yaklaşımının veri toplama araçlarından görüşme tekniği kullanılmıştı. Fenomenolojik araştırmalarda başlıca veri toplama aracı görüşmedir. Olgulara ilişkin yaşantıları ve anlamları ortaya çıkarmak için görüşmenin araştırmacılara sunduğu etkileşim, esneklik ve sondalar yoluyla irdeleme özelliklerinin kullanılması gerekmektedir (Yıldırım \& Şimşek, 2013, s. 80).

Görüşme tekniği için veri toplama aracı olarak yarı yapılandırılmış görüşme formu (Merriam, 2009) hazırlanmıştır. Yarı yapılandırılmış form ile yapılan görüşmelerde, sorular önceden belirlenmiş ve hangi tür verilerin toplanacağı ayrıntılı bir şekilde belirlenir (Karasar, 2013, s. 167). Uzman görüşüne başvurularak hazırlanan soruların bazıları araştırmanın amacına uygun olmadığı için görüşme formundan çıkarılmış ve yerine yeni sorular ilave edilmiştir. Görüşme formunda öğrencilere bitki coğrafyası ile ilgili sekiz adet kısa ve açık uçlu soru sorulmuştur. Çalışmaya katılan öğrencilerin cevapları araştırmanın amacına göre kodlanmış tablolaştrılmış ve bulgular bölümünde sunulmuştur.

\section{Verilerin Analizi}

$\mathrm{Bu}$ çalışma sırasında elde edilen veriler nitel veri analiz tekniklerinden biri olan betimsel analiz yöntemiyle çözümlenmiştir. Fenomenoloji araştırmalarında veri analizi, yaşantıları ve anlamları ortaya çıkarmaya yöneliktir. Bu amaçla yapılan içerik analizinde verinin kavramsallaştırılması ve olguyu tanımlayabilecek temaların ortaya çıkarılması çabası vardır. Sonuçlar betimsel bir anlatımla sunulur. Bunun yanında ortaya çıkan temalar ve örüntüler çerçevesinde elde edilen bulgular açıklanır ve yorumlanır (Yıldırım \& Şimşek, 2013, s. 81)

Öğrencilere verilen görüşme formunda bitki coğrafyası kavramını nasıl algıladıkları ile ilgili sorular sorulmuştur. Öğrencilerin verdiği cevap metinleri baştan sona okunmuş, kelime öbekleri ve kavramlar kodlanmış, kodlar arasındaki benzerlik ve farklılıklardan yola çıkarak kategoriler (tema) oluşturulmuştur. Oluşturulan bu kod ve temalardan hareketle betimsel yorumlar yapılmıştır. Sorulardan elde edilen bulgular tablolara işlenerek görsel hâle getirilmişsir.

Araştırmada kullanılan yarı yapılandırılmış görüşme formundaki veriler analiz edilirken katılımcı öğrenciler Ö1, Ö2, Ö3 şeklinde kodlanırken, öğrenci görüşleri [1], [2], [3] şeklinde kodlanmıştır.

\section{Bulgular}

Bu araştırmada, ortaöğretim coğrafya müfredatındaki bitki coğrafyası kazanımlarının, öğrencilerin bitkileri tanımalarında ne derece etkili olduğunu ele alan sorulara cevap verilmeye çalışıımıştır. Araştırma problemlerinden öncelikle "Ortaöğretim coğrafya programındaki bitki coğrafyası konusu kazanımları yeterli sayıda mıdır?" sorusunun cevabı aranmıştır. Bu amaçla Millı̂ Eğitim Bakanlığı Talim Terbiye Kurulu tarafindan hazırlanan 2014-2015 öğretim yılında kullanılan Coğrafya öğretim programı incelenmiş, bitki coğrafyası ile ilgili tespit edilen bölümler ve kazanımlar Tablo.02ve Tablo.03'de sunulmuştur.

Coğrafya öğretim programı 2014 incelenmiş, coğrafya dersi öğretim programının genel amaçları kısmında bitki coğrafyası ile ilgili tespit edilen bölümler Tablo.02'de gösterilmiştir. Doğal sistemler, insan-doğa ilişkisi, yakın çevredeki mekânsal değerler, ekosistemin işleyişi, çevre sorunları, Türkiye'nin konumu ve özellikleri vatan bilinci gibi amaçlar içerisinde bitki coğrafyasına da atflar yapılmaktadır.

Coğrafya öğretim programını incelendiğinde sadece beş kazanımda bitki ve bitki coğrafyası terimlerinin geçtiği

| Kastamonu Eğitim Dergisi, 27(5), 2019| 
görülür. 10.sınıf "Ünite, Kazanım, Etkinlik Örnekleri ve Açıklamalar" tablosunda (Tablo.02) kazanımlar, bitki coğrafyası ve öğretilmesi gereken bitkiler ile alakalı konular izah edilmektedir. Kazanım A.10.4. Bitki tür ve topluluklarını genel özelliklerine göre sınıflandırılması, Kazanım A.10.5. Farklı bitki topluluklarının dağılışı ile iklim ve yer şekilleri ile ilişkilendirilmesi ve Kazanım C.10.9. Türkiye'deki doğal bitki topluluklarının dağııı̧ını yetişme şartlarının incelenmesi hususlarından bahsetmektedir.

\section{Tablo 2. Coğrafya Öğretim Programında Bitki Coğrafyası ile Alakalı Bölümler}

\section{COĞRAFYA DERSI ÖĞRETIM PROGRAMI'NIN GENEL AMAÇLARI}

Coğrafya Dersi Öğretim Programı ile öğrenci;

İnsan - doğa ilişkisi çerçevesinde coğrafi sorgulama becerileri kazanır.

Doğal ve beşerî sistemlerin işleyiş ve değişimini kavrar.

Yakın çevresinden başlayarak ülkesine ve dünyaya ait mekânsal değerlere sahip çıkma bilinci geliştirir.

Ekosistemin işleyişine yönelik sorumluluk bilinci geliştirir.

Doğa ve insanın uyumlu birlikteliği ve sürekliliği için mekânsal planlamanın önemini kavrar.

Doğal afetler ve çevre sorunlarını değerlendirerek korunma ve önlem alma yollarına yönelik uygulamalar geliştirir.

Coğrafi birikim ve sentez ülkesi olan Türkiye'nin bölgesel ve küresel ilişkiler açısından konum özelliklerini kavrayarak sahip olduğu potansiyelin bilincine varır.

Coğrafi değerlerin "vatan bilincinin" kazanılmasındaki önemini özümser. (MEB, 2011)

Tablo 2. Coğrafya Öğretim Programında Bitki Coğrafyası ile Alakalı Bölümler

\section{ÖĞRENME ALANI: A. DOĞAL SISTEMLER}

A.10.4. Bitki tür ve topluluklarını genel özelliklerine göre sınıflandırır.

Tür ve Toplulukları Tanıyalım: Bitkilerle ilgili imkanlar ölçüsünde farklı türlerden numuneler toplayarak sınıfa getirilmesi istenir. Ya da farklı türlere ait bitki resimleriyle ilgili koleksiyon oluşturulması istenilebilir. Elde edilen materyaller sınıf içinde benzer ve farklı özelliklerine göre gruplandırılarak öğrencilerden bu materyalleri, yorumlamaları istenebilir.

A.10.5. Farklı bitki topluluklarının dağılışı ile iklim ve yer şekillerini ilişkilendirir.

Dünyayı Kaplayan Örtü: Bitkiler Bilgi kese kâğıdı tekniği ile bitki topluluklarının genel özellikleri ve dünya üzerinde görüldüğü alanlar sınıflandırılır. Elde edilen bilgiler harita üzerine aktarılarak iklim ve yer şekillerinin dağılışı ile ilişkilendirilebilir.

C.10.9. Türkiye'deki doğal bitki topluluklarının dağılışını yetişme şartlarıyla ilişkilendirerek analiz eder.

Bitkiler Türkiye'deki bitki tür ve çeşitliliğini, dağılışını, yetişme şartlarını vurgulayan reklam metinleri, kısa reklam filmleri veya afişler hazırlanabilir. Türkiye'deki endemik ve relikt bitkilerin dağılış ve önemleri de vurgulanır.

A.11.1. Biyoçeşitliliğin oluşumunda ve azalmasında etkili olan faktörleri sorgular.

Bozulan Dengeler: Haritalar incelenerek bitki ve hayvan türlerinin zenginliği ve dağılışı ile doğa unsurlarının ilişkisi kurulur. Dünyadaki tür zenginliğinin nedenleri ile türlerin azalmasına neden olan faktörler ilişkilendirilerek raporlar oluşturulabilir.

C.12.1.Bölge tanımlama ve sınıflandırılmasında kullanılan kriterler açısından ülkemizdeki farklı bölge türlerini haritalar üzerinde örneklendirir

Mekânsal Zenginliğimiz: İklim, yer şekilleri, bitki örtüsü, nüfus ve ekonomik faaliyetleri gösteren haritalar incelenir. Dilsiz Türkiye haritaları üzerinde Belirlenen kriterlere uygun bölgeler oluşturulur. (MEB, 2011)

Ayrıca Tablo 3'te yer alan bir tane 11.sınıf ve bir tanede 12.sınıf kazanımının açıklamalar kısmında bitkilerden bahsedilmektedir. Her iki tablodan (Tablo 2, 3) da anlaşılacağı üzere bitki coğrafyası, Coğrafya öğretim programında 10.sınıf kısmında Doğal Sistemler ünitesinin önemli konuları arasında yer almaktadır. Dünyadaki ve Türkiye'deki bitki topluluklarının özellikleri, dağılışı ve doğal şartlara uyumunun öğrenciler tarafindan bilinmesi, analiz edilmesi ve yorumlanması programın önemli hedefleri arasındadır. Ancak bu veriler ışığında bitki coğrafyasının sadece üç kazanım ile veriliyor olması, 11. ve 12.sınıfların programında sadece iki kazanımın açıklamalar kısmında değinilmesi böyle önemli bir konuya az önem ve 
zaman ayrıldığını, programındaki bitki coğrafyası konusu kazanımlarının yeterli sayıda olmadığını göstermektedir.

Araştırmanın ikinci ve üçüncü alt problemleri olan "coğrafya müfredatındaki bitki coğrafyası kazanımlarının, öğrencilerin bitkileri tanımalarında etkisi var mıdır? ve öğrencilerin coğrafya dersinde gördüğü bitki coğrafyası konuları, öğrencilerde bitkileri tanıma konusunda bir merak, bilinç ve farkındalık oluşturmakta mıdır?" soruları için sekiz adet açık uçlu soru hazırlanmıştır. Öğrencilere yöneltilen sekiz adet kısa ve açık uçlu soruya öğrencilerin verdiği farklı cevaplar, açıklamalar ve birden çok açıklama ifadesi, cevapları daha iyi değerlendirmek için "çok az", "az", "yeterli", "iyi" ve "çok iyi" gibi kategorilere ayırma mecburiyeti getirmiştir. Bütün soruların cevaplarında bu kategorilere bölme yapılmıştır. Bu sebeple birbirine benzeyen ve yakın anlam ifade eden cümleler birleştirilmiş ve tablolarda kategori frekansı (f) toplamı sütununda verilmiştir.

\section{Lisede edindiğiniz bilgileriniz dışında daha önce bitkiler hakkında ne seviyede bir bilgiye sahiptiniz?}

Öğrencilere yöneltilen sorulardan birincisi olan, "liseden önce bitkiler hakkındaki bilgi seviyesi" konusundaki soruya öğrencilerin verdiği cevapların yarısından fazlası $(\% 57,5)$ bilgilerinin "az" ve "çok az" olduğunu ifade etmiştir (Ö16, Ö27). "Yeterli-orta", "iyi", "Çok iyi" olduğunu ifade edenler ise yarıdan az $(\% 42,5)$ seviyededir. Frekansı en yüksek cevap ise "az" kategorisinde olan "Bitki denince aklıma sadece ağaçlar geliyordu." cevabı oluşturmaktadır. İkinci en yüksek frekansa sahip cevap ise "yeterli-orta" kategorisindeki "Akrabalarım çiftçi olduğu için bazı şeyler onlardan öğrendim." Bu sonuçlara göre Anadolu lisesi 10.sınıf öğrencilerin liseden önce bitkiler hakkındaki bilgilerinin düşük seviyede olduğu görülmüştür (Tablo 4). "Biyoloji dersinde bazı konuları öğrenmiştim(Ö11)." Cevabını veren bazı öğrenciler bu soruda disiplinler arsı etkileşime dikkat çekmiştir.

Tablo 4. Öğrencilerin liseden önceki dönemde bitkiler hakkındaki bilgileri

\begin{tabular}{|c|c|c|c|c|}
\hline Öğrencilerin ífadeleri & f & Kategorisi & Kategori f Toplamı & $\%$ \\
\hline [1] Hiç bilgim yoktu. & 2 & Çok az & 2 & 5,0 \\
\hline [2] Farkında değildim. & 7 & & & \\
\hline [2] Bitki denince aklıma sadece ağaçlar geliyordu. & 8 & & & \\
\hline [2] Bir kısmını dedem anlatmışt. & 4 & $A z$ & 21 & 52,5 \\
\hline [2] Pikniğe gittiğimizde görüp merak ederdim, anneme sorardım. & 2 & & & \\
\hline [3] Akrabalarım çiftçi olduğu için bazı şeyler onlardan öğrendim. & 7 & & & \\
\hline [3] Annem saksıda çiçek ve bazı sebzeler yetiriyor, oradan biliyorum. & 2 & Yeterli-orta & 9 & 22,5 \\
\hline [4 Biyoloji dersinde bazı konuları öğrenmiştim. & 1 & & & \\
\hline [4] Ortaokulda fen dersinde öğrendim. & 2 & Jivi & 3 & 125 \\
\hline $\begin{array}{l}\text { [4] Kendi bahçemiz var. Orada hem sebze yetiştiriyoruz hem de mey- } \\
\text { ve ağaçlarımız var. Onların bakımını babamla yaparken öğrendim. }\end{array}$ & 2 & & & \\
\hline [5] Bitkilere ilgim var, araştrıyorum. & 3 & Çok İyi & 3 & 7,5 \\
\hline TOPLAM & 40 & & 40 & 100 \\
\hline
\end{tabular}

Bu durum öğrencilerin bitkilere yabancı olmadıkları ancak bilgi seviyelerinin düşük olduğu, hatta bazı öğrencilerin çevrelerindeki bitkilerin hiç farkında dahi olmadıklarını ortaya koymaktadır.

\section{Ortaöğretim hayatınızda daha çok hangi derste bitkiler hakkında bilgi elde ettiniz?}

Öğrenciler, lise öğrenimlerine devam ederken daha çok hangi derste bitkiler hakkında bilgi edindiklerinin sorulduğu bu soruya coğrafya, biyoloji, edebiyat, İngilizce ve resim derslerinin ismi vermiştir. Bu dersler içerisinde frekans (f:38) ve yüzdeliği $(\% 52,78)$ en fazla olan dersler coğrafya ve biyoloji (f:29 ve \%40,28) olarak ön plana çıkmaktadır. Çünkü birçok öğrenci hem coğrafya hem de biyoloji dersini bu soruda ortak cevap olarak vermiştir. Bu çift cevaplamalardan dolayı frekans toplamı da öğrenci sayısından fazla çıkmaktadır. Coğrafya dersinde ve biyoloji dersinde bitkilerin en az birkaç kazanımda yer alması, öğretmenlerin bitkileri geniş bir şekilde izah etmesi ve ders kitaplarında bunların açıklanması, resimlerinin yer alması öğrencilerin (Ö2, Ö9, Ö36, Ö39) bu soruya bu iki dersi yazmalarındaki sebepler olarak karşımıza gelmektedir (Tablo 5). 
Tablo 5. Öğrencilerin lise döneminde en çok hangi derste bitkiler hakkındaki bilgi edindikleri

\begin{tabular}{|c|c|c|c|c|}
\hline Öğrencilerin ífadeleri & f & Kategorisi & Kategori f Toplamı & $\%$ \\
\hline $\begin{array}{l}\text { [1] En çok coğrafya dersinde bilgi elde ettim, çünkü dersimizin bir üni- } \\
\text { tesi bitki coğrafyası ve öğretmenimiz anlatt. }\end{array}$ & 16 & & & \\
\hline $\begin{array}{l}\text { [1] En çok coğrafya dersinde bilgi elde ettim, çünkü ders kitabında bazı } \\
\text { bölümlerde bitkiler ile bilgi bulunuyor. }\end{array}$ & 12 & Coğrafya & 38 & 52,78 \\
\hline $\begin{array}{l}\text { [1] En çok coğrafya dersinde bilgi elde ettim, çünkü ders kitabında bazı } \\
\text { bölümlerde bitkiler şekiller, resimler ve etkinlikler bulunuyor }\end{array}$ & 10 & & & \\
\hline $\begin{array}{l}\text { [2] En çok biyoloji dersinde bilgi elde ettim, çünkü dersimizin bir üni- } \\
\text { tesi bitki coğrafyası ve öğretmenimiz anlatt. }\end{array}$ & 14 & & & \\
\hline $\begin{array}{l}\text { [2] En çok biyoloji dersinde bilgi elde ettim, çünkü ders kitabında bazı } \\
\text { bölümlerde bitkiler ile bilgi bulunuyor. }\end{array}$ & 8 & Biyoloji & 29 & 40,28 \\
\hline $\begin{array}{l}\text { [2] En çok biyoloji dersinde bilgi elde ettim, çünkü ders kitabında bazı } \\
\text { bölümlerde bitkiler şekiller, resimler ve etkinlikler bulunuyor. }\end{array}$ & 7 & & & \\
\hline [3] En çok edebiyat dersinde bilgi elde ettim. & 3 & Edebiyat & 3 & 4,17 \\
\hline [4] En çok ingilizce dersinde bilgi elde ettim. & 1 & İngilizce & 1 & 1,39 \\
\hline [5] En çok resim dersinde bilgi elde ettim. & 1 & Resim & 1 & 1,39 \\
\hline TOPLAM & 72 & & 72 & 100 \\
\hline
\end{tabular}

Coğrafya dersinde gördüğünüz bitki coğrafyası konuları sizde bitkileri tanıma konusunda nasıl bir farkındalık ve bilinç oluşturdu?

Araştırmaya katılan öğrenciler coğrafya dersinde gördükleri bitki coğrafyası konularının, onlarda bitkileri tanıma konusunda pozitif bir farkındalık ve bilinç oluşturduğu ifade etmişlerdir. Bazı öğrenciler "daha önce farkında olmadı̆̆ım bu doğal değerleri bana tanıtt" (Ö18, Ö23) bazıları ise "hep yanı başımızda iken ben farkında değilmişim” (Ö8, Ö17, Ö33) şeklinde olumlu değişikliği ifade eden cevaplar vermişlerdir. Tablo.06 incelendiğinde coğrafya dersinin bitkileri tanıma konusunda bir farkındalık ve bilinç oluşturup oluşturmadığı konusunda öğrencilerin \%67,5'i (iyi ve çok iyi kategorisinde) olumlu görüş bildirmişlerdir. Öğrencilerin \%12,5'i orta seviyede katkı sağladığını ifade ederken, olumsuz görüş bildirenler (az, çok az kategorisi) \%12,5'te kalmıştır (Tablo 6). Ayrıca öğrenciler coğrafya dersinde gördükleri bitki coğrafyası konularından sonra çevrelerindeki bitkilere daha başka bir gözle baktıklarını yaptığımız görüşmelerde ifade etmişlerdir.

Tablo 6. Coğrafya dersinde görülen bitki coğrafyası konularının öğrencilerde bitkileri tanıma konusunda oluşturduğu farkındalık ve bilinç tablosu.

\begin{tabular}{|c|c|c|c|c|}
\hline Öğrencilerin İadeleri & f & Kategorisi & Kategori f Toplamı & $\%$ \\
\hline [1] Daha önce farkında olmadığım bu doğal değerleri bana tanıtt. & 7 & & & \\
\hline [1] Hep yanı başımızda iken ben farkında değilmişim. & 6 & Çok iyi & 13 & 32,50 \\
\hline $\begin{array}{l}\text { [2] Karadeniz iklimi ile Akdeniz ikliminde farklı bitki türlerinin yetişti- } \\
\text { ğini anladım }\end{array}$ & 8 & & & \\
\hline [2] Bitkilerin yetişme sürelerinin farklı olduğunu anladım. & 5 & İyi & 17 & 42,50 \\
\hline [2] Makilerin ağaç olmadığını öğrendim. & 4 & & & \\
\hline [3] Her iğne yapraklı ağaç çam değilmiş. & 2 & & & \\
\hline [3] Ağaçların adını öğrendim. & 2 & Yeterli-orta & 5 & 12,50 \\
\hline [3] Her bitkinin ağaç olmadığı gördüm. & 1 & & & \\
\hline [4] Eski bildiklerime benzer şeyler öğrendim. & 3 & $\mathrm{Az}$ & 3 & 7,50 \\
\hline [5] Pek bir şey öğrenmedim. & 2 & Çok Az & 2 & 5,00 \\
\hline TOPLAM & 40 & & 40 & 100 \\
\hline
\end{tabular}

Coğrafya dersinde elde ettiğiniz bu bilgilerden sonra yaşadığınız çevrenizdeki ve okulunuz bahçesindeki bitkiler hakkında görüşünüz değişti mi?

Coğrafya dersinde bitki coğrafyası konularının işlenmesinden sonra elde edilen bilgilerin ışığında çevrenizdeki ve okul bahçesindeki bitkiler hakkındaki görüşünün sorulduğu bu soruda, öğrencilerin \% 72,5'i (iyi ve çok iyi kategorisi) bitkileri çok merak ettiklerini hatta ilk ders arasında gidip bu bitkileri, özellikle ağaçları saydıklarını (Ö6, Ö10, Ö21 Ö29) ifade etmişlerdir (Tablo 7). Bazı öğrenciler ders hocalarııın anlatttkların çok ilginç olduğunu daha önce farkında olmadıkları bu doğal zenginliğin değerini anladıklarını belirtmiştir (Ö5, Ö9, Ö19). Bitkilerin dikkatlerini çekmediğini, görüşlerinin değişmediğini (Ö16, Ö27) ifade eden öğrenci oranı ise (az, çok az kategorisi) \%10 seviyesinde kalmıştır. 
Orta seviyedeki öğrenci oranı ise \%17,5'tir. Bu sonuçlar göstermektedir ki çevremizdeki bitkilerin önemi ve özellikleri gençlere anlatıldığında önemleri daha çok anlaşılacaktır.

Tablo 7. Coğrafya dersinde elde edilen bilgilerden sonra öğrencilerin yaşadığı çevresinde ve okul bahçesindeki bitkiler hakkında görüşleri.

\begin{tabular}{|c|c|c|c|c|}
\hline Öğrencilerin ifadeleri & $f$ & Kategorisi & Kategori f Toplamı & $\%$ \\
\hline $\begin{array}{l}\text { [1] Ders hocamızın bize anlattıları çok ilginçti. Daha önce farkında olmadı- } \\
\text { ğım bu doğal zenginliğin değerini anladım. }\end{array}$ & 6 & \multirow{2}{*}{ Çok iyi } & \multirow{2}{*}{12} & \multirow{2}{*}{30,00} \\
\hline $\begin{array}{l}\text { [1] O kadar çok merak ettim ki ilk ders arasında gidip bu bitkileri özellikle } \\
\text { ağaçları saydım. }\end{array}$ & 6 & & & \\
\hline [2] Ülkemizin önemli ekonomik kaynaklarındanmış haberim yokmuş. & 6 & \multirow{3}{*}{ İyi } & \multirow{3}{*}{17} & \multirow{3}{*}{42,50} \\
\hline [2] Neden çevremde daha çok ağaç yok diye düşünmeye başladım. & 8 & & & \\
\hline [2] Kullandığımız kağı̆tlar ülkemiz milli servetinin ürünü olduğunu anladım. & 3 & & & \\
\hline [3] Bütün canlılar benim için önemlidir. & 4 & \multirow{2}{*}{ Yeterli-orta } & \multirow{2}{*}{7} & \multirow[b]{2}{*}{17,50} \\
\hline [3] Ailem de bu konuda bana hep bilgi vermektedir. & 3 & & & \\
\hline [4] Eski bildiklerime benzer şeyler öğrendim. & 2 & $A z$ & 2 & 5,00 \\
\hline [5] Pek bir şey öğrenmedim. & 2 & Çok $A z$ & 2 & 5,00 \\
\hline TOPLAM & 40 & & 40 & 100 \\
\hline
\end{tabular}

Coğrafya dersinde, bitki coğrafyası konusunda elde ettiğiniz bu bilgilerden yola çıkarak okul bahçenizdeki ve çevrenizdeki bitkileri (özellikle ağaçları) tanıyabildiniz mi? Çevrenizde tanıyabildiğiniz bitkilerin isimlerini yazabilir misiniz?

Araştırmanın bu sorusuna öğrencilerin \%47,5'i ise olumlu (iyi ve çok iyi kategorisi) cevaplarını verir iken, \%35'i orta düzeyde merak ettiklerini ve \%17,5’i (az, çok az kategorisi) ise olumsuz cevap bildirmişlerdir (Tablo 8) Çok ve çok iyi kategorisinin diğer sorularda olduğu kadar yüksek bir oranda çıkmasa da sonuçlar öğrencilerin bu konuda istekli olduklarını göstermektedir. Öğrencilerin okul bahçelerindeki, mahallelerindeki, apartman bahçelerindeki ağaçların farklı farklı olduğunu (Ö3, Ö4, Ö14 Ö25), ağaç-çalı-ot formasyonları arasında bazı farkların bulunduğunu (Ö10, Ö23), bunların adlarını öğrenmek istediklerini (Ö7, Ö36) ifade etmişlerdir. Bazı öğrenciler bütün bitkilere ağaç deyip geçtiklerini, ancak bundan sonra bu konuya dikkat edeceklerini belirtmiştir (Ö12, Ö18).

Tablo 8. Coğrafya dersinde, bitki coğrafyası konusunda elde edilen bilgilerden yola çıkarak öğrencilerin okul bahçenizdeki ve çevrelerindeki bitkileri (özellikle ağaçları) tanıyabilme oranı.

\begin{tabular}{|c|c|c|c|c|}
\hline Öğrencilerin İfadeleri & f & Kategorisi & Kategori f Toplamı & $\%$ \\
\hline [1] Çok iyi tanıdım. & 5 & \multirow{2}{*}{ Çok iyi } & \multirow{2}{*}{9} & \multirow{3}{*}{22,50} \\
\hline [1] Mutlaka öğrenmem gereken bir konu. & 4 & & & \\
\hline [2] Bilgiyi kullanmak hoşuma gitti. & 3 & \multirow{3}{*}{ İyi } & \multirow{3}{*}{10} & \\
\hline [2] Severek tanımaya çalıştım. & 4 & & & \multirow{2}{*}{25,00} \\
\hline $\begin{array}{l}\text { [2] Kardeşim ile bilgileri paylaştım. Bahçemizdeki ağaçları tahmin et- } \\
\text { meye çalıştım. }\end{array}$ & 3 & & & \\
\hline [3] Çok çalışma gerektiriyor. Sanki zor biraz. & 7 & \multirow{3}{*}{ Yeterli-orta } & \multirow{3}{*}{14} & \multirow{3}{*}{35,00} \\
\hline [3] Tanımakta zorlanmadım. & 4 & & & \\
\hline [ ${ }_{3}$ ] Ailem de bu konuda bana hep bilgi vermektedir. & 3 & & & \\
\hline [4] Bilmesem de olur, bilmesem de. & 3 & $\mathrm{Az}$ & 3 & 7,50 \\
\hline [5] Bana göre gereksiz. Ormancı olmayacağım. & 4 & Çok Az & 4 & 10,00 \\
\hline TOPLAM & 40 & & 40 & 100 \\
\hline
\end{tabular}

Araştırmanın yapıldığı kurumların bahçelerinde iğne ve geniş yapraklı birçok ağaç türü bulunmasına rağmen, öğrencilerin öğrendikleri ağaç türlerinden tanıyabildiklerinin isimlerini yazdıklarında, en çok kavak(18), meşe(16), kestane(12), gürgen(11), palamut(11), karaçam(9) ve kızılçam(8) ağaç türlerini sayabilmişlerdir.

\section{Coğrafya dersinde gördüğünüz bitki coğrafyası konularını severek takip ettiniz mi?}

Öğrenciler araştırmanın bu sorusuna\%30 oranında olumlu (iyi ve çok iyi kategorisi), \%32,5 oranında orta ve \%37,5 oranında ise olumsuz (az, çok az kategorisi) cevap bildirmişlerdir (Tablo 9). Bu soruda olumlu cevapların azalmasında öğretmenlerin ders ilenişinde kullandıkları yöntem ve teknikler (Ö18), okulun fiziki imkanları (Ö6, Ö27), öğrencilerin hazır bulunuşlukları gibi sebeplerin etkili olduğu öğrenciler ve öğretmenler ile yapılan birebir görüşmelerden anlaşılmıştr. 
Tablo 9. Coğrafya dersinde görülen bitki coğrafyası konularının öğrenciler tarafından severek takip edilip edilmediğine dair oranlar tablosu

\begin{tabular}{|c|c|c|c|c|}
\hline Öğrencilerin İfadeleri & f & Kategorisi & Kategori f Toplamı & $\%$ \\
\hline [1] Ders çok eğlenceli idi. & 2 & \multirow{2}{*}{ Çok iyi } & \multirow[b]{2}{*}{5} & \multirow{2}{*}{12,50} \\
\hline [1] Dersi merak ile izledim. & 3 & & & \\
\hline [2] Doğaya ve çevreye saygı açısından önemlidir. & 2 & \multirow{3}{*}{ İyi } & \multirow{3}{*}{7} & \multirow{3}{*}{17,50} \\
\hline [2] Yaşadığımız mekanları daha bilmem için faydasını gördüm. & 4 & & & \\
\hline [2] Ekonomiye katkısını merakla dinledim. & 1 & & & \\
\hline [3] Ülkemizde yaşayan herkes için normalde bilinmesi gerekir. & 6 & \multirow{4}{*}{ Yeterli-orta } & \multirow{3}{*}{13} & \multirow{3}{*}{32,50} \\
\hline [3] Her gün karşılaştı̆ım bir konu olduğundan fazla heyecan duymadım. & 3 & & & \\
\hline [3] Coğrafya dersinin klasik bir konusu. & 4 & & & \\
\hline [4] Hocamız sadece anlatıp geçti. & 2 & & \multirow{3}{*}{11} & \multirow{3}{*}{27,50} \\
\hline [4] Ezberlenecek kavram ve isimler çok fazla. & 5 & \multirow[t]{2}{*}{$A z$} & & \\
\hline [4] Dersin çabuk bitmesini bekledim. & 4 & & & \\
\hline [5] Daha önce hiç işlemediğimiz bir konu, ne işime yarayacak. & 2 & \multirow[b]{2}{*}{ Çok Az } & \multirow[b]{2}{*}{4} & \multirow[b]{2}{*}{10,00} \\
\hline [5] Sıkıcı bir konuydu. Heyecan duymadım. & 2 & & & \\
\hline TOPLAM & 40 & & 40 & 100 \\
\hline
\end{tabular}

\section{Coğrafya dersinde gördüğünüz bitki coğrafyası konuları yeterli mi?}

Bu soruda kategorilerde "iyi" kategorisi yerine "fazla" kategorisi kullanılmıştır. Araştırmanın bu sorusuna konuya ilgi duyup arttıııması isteyen öğrencilerin (Ö10, Ö12) oranı (az ve çok az kategorisi) oranı \%37,5 iken, öğrencilerin yarısından fazlası yeterli (\%55) olup, daha fazlasına gerek olmadığını (Ö1, Ö23, Ö40) ifade etmişlerdir. Konuya ilgi duymayıp, ders saatini ve konunun ünitedeki yerini çok bulup azaltılmasını (Ö16, Ö27, Ö34, Ö40) isteyenlerin (çok, çok fazla kategorisi) oranı \%7,5 seviyesindedir (Tablo 10). Bu soruda da öğrencilerden coğrafya dersine yönelik olumlu bir sonuç ortaya çıkmıştır.

Tablo 10. Coğrafya dersinde görülen bitki coğrafyası konularının yeterli olup olmadığına dair tablo

\begin{tabular}{|c|c|c|c|c|}
\hline Öğrencilerin Ifadeleri & $\mathrm{f}$ & Kategorisi & Kategori f T. & $\%$ \\
\hline [1] Bu konu için yeterli hatta fazla bile & 1 & & & \\
\hline [1] Sıkıcı buldum, gereksizdir. & 1 & Çok fazla & 2 & 5,00 \\
\hline [2] Normal bir konu için abartmaya gerek yok. & 1 & Fazla & 1 & 2,50 \\
\hline [3] Yeterlidir. Ekstra bir şey yapılması gereksiz. & 7 & & & \\
\hline [3] Bitki coğrafyası konusu için zaman ve üniteler yeterlidir. & 9 & Yeterli-orta & 22 & 55,00 \\
\hline [3] iki haftalık derste öğrenebildim. Süre tam yetti. & 6 & & & \\
\hline [4] Doğaya ve çevreye saygı açısından zaman biraz azdı. & 4 & & & \\
\hline [4] Bitkileri tanımak için konu içeriği ve zaman yetersiz & 3 & $A z$ & 11 & 27,50 \\
\hline [4] Bitkiler konusu çabuk bitti, biraz daha uzun olabilirdi. & 4 & & & \\
\hline [5] Ders çok eğlenceli idi. Zaman hiç yetmedi & 2 & & & \\
\hline $\begin{array}{l}\text { [s] Dersi merak ile izledim. Konular bana az geldi. Daha ayrıntlı } \\
\text { olma gerekir. }\end{array}$ & 2 & Çok Az & 4 & 10,00 \\
\hline TOPLAM & 40 & & 40 & 100 \\
\hline
\end{tabular}

Bitki coğrafyası konusu ile ilgili kazanımların daha iyi anlaşılması ve sizlerin konuyu daha iyi kavraya bilmeniz için ne gibi etkinlikler yapılabilir?

Araştırmanın bu sorusuna öğrenciler güzel cevaplar vermiş ve ilginç öneriler sunmuştur. Her öğrencinin verdiği cevaplar kategorilere ayrılarak frekans değerine göre Tablo 11'de sıralanmıştı. Buna göre öğrenciler, coğrafya dersinde geziler yapılmak, araziye çıkılmak, sınıfa yapraklar getirmek gibi bitkileri tanıtıcı materyal getirilmek, yaprak koleksiyonu yapmak, ağaçlarla ilgili sunum hazırlamak, yörenin yaşlı insanları ile ağaçlar üzerine röportaj yapmak, konu ile ilgili fotoğraf arşivi oluşturmak, ağaç dikim kampanyası yapmak veya katılmak, bitkiler ile ilgili belgeselleri izlemek, ağaçlar ile ilgili şiir yazmak gibi önerilerde bulunmuşlardır. 
Tablo 11. Bitki coğrafyası konusu ile ilgili kazanımların daha iyi anlaşılması için önerilen etkinliklerin frekans dağılımı.

\begin{tabular}{lc}
\hline Etkinlik & $\mathbf{f}$ \\
\hline Geziler yapmak & 15 \\
Araziye çıkmak & 11 \\
Bitkiler ile ilgili belgesel izlemek & 7 \\
Ağaç dikim kampanyası yapmak veya katılmak & 6 \\
Sınıfa yaprak getirmek & 6 \\
Yaprak koleksiyonu yapmak & 5 \\
Ağaçlarla ilgili sunum hazırlamak & 5 \\
Yaşlı insanlar ile ağaçlar üzerine röportaj yapmak & 3 \\
Konu ile ilgili fotoğraf arşivi oluşturmak & 2 \\
Ağaçlar ile ilgili şiir yazmak & 1 \\
\hline
\end{tabular}

\section{Sonuç ve Tartışma}

Ortaöğretim coğrafya müfredatındaki bitki coğrafyası kazanımlarının, öğrencilerin bitkileri tanımalarında ne derece etkili olduğunun belirlemek üzere yaptı̆ımız bu çalışma bizlere coğrafya dersinin öğrenciler üzerinde olumlu neticeler doğurduğunu göstermektedir. Öğrencilerin bu dersten sonra gidip okul bahçesindeki bitkileri gözlemlemeleri, onları saymaları, coğrafya öğretmenlerinin derste bu konudaki gayretli tutumu önemli bir paya sahiptir.

Bu araşttrmada elde edilen bulgulara göre, bazı öğrenciler bitki coğrafyasını, coğrafya dersinin asli bölümlerinden biri olarak görmekte iken, bazıları ise gereksiz ve zaman kaybı olarak görmektedir. Yine bitki coğrafyası öğrenciler arasında daha çok coğrafya dersinin bir parçası olarak düşünülmektedir. Coğrafya dersi öğretim programı kazanımları ve ders kitaplarının önemli olduğuna, coğrafya dersi yanında diğer derslerde de bu konunun önemsenmesi gerektiği sonucu tespit edilmiştir.

Araştırmada öğrenciler bitki konularının daha iyi öğrenilebilmesi için getirdikleri öneriler arasında "coğrafya dersinde geziler yapılmak ve araziye çıkılmak" gibi önerilerin bulunması zaman sıkıntısı, mekân sıkıntısı ve sınıfların kalabalık oluşu gibi sebepler ile bitki konularının arazi çalışmaları ile desteklenemediği göstermiştir. Birçok öğrencinin çevresindeki bitkilerin farkında olmadığı sonucu ortaya çıkmıştır. Bazı öğrencilerin coğrafya dersindeki bitki coğrafyası kazanımlarından sonra okul bahçesindeki bitkilere daha bir başka gözle baktıkları, hatta ağaç sayısını merak ettikleri için saydıklarını ifade etmeleri bu konuların öğrencilerde olumlu neticeler çıkardığını gözler önüne sermektedir. Ağaçlar, çalılar ve otlar arasındaki farkı bilmeyen öğrenciler ve bu yaş grubu için bu gelişme önemlidir. Öğrencilerin velilerini bu konuda sorguya çektikleri daha sorgulayıcı ve merak duygusu içerisine girdikleri verilen cevaplardan ortaya çıkmaktadır. Bitki coğrafyası kazanımlarının ardından öğrenciler bitkiler arasındaki formasyon ayırımını görmüşlerdir. Örneğin her iğne yapraklı ağacın çam olmadığı, makilerin ağaç olmadığı, her bitkiye ağaç denmediğini öğrendikleri gibi. Bu verilere göre öğrenciler coğrafya dersinde çevremizdeki bitkileri tanımada onların ot, çalı ağaç gibi formasyonlara ayrıldığını, farklı iklim şartlarında yetiştiğini, her bölgede aynı bitki türünün iklim, yer şekli, toprak özellikleri ve su istekleri gibi faktörlerden dolayı görülemeyeceğini \%87,5 gibi bir oranla öğrenmiş bulunmaktadırlar.

Bu araştırma neticesinde bitki coğrafyası konusunun aynı zamanda disiplinler arası bir konu olduğu, öğrencilerin coğrafya ile beraber biyoloji dersinde de bu konuda bilgiler edindiklerini ifade etmişlerdir. ilıseven ve diğerlerinin (2017) yöneticiler ve öğretmenler üzerinde yaptığı benzer çalışmada, bitki coğrafyası ile ilgili Avrupa ülkelerinde kullanılan eğitim sisteminin çok etkili olduğu ancak bunun Kıbrıs'ta uygulanmadığı için öğrencilerin bitkileri öğrenemediği vurgulanmıştır. Ayrıca yine aynı çalışmada, vejetasyon coğrafyası eğitiminin doğa hakkındaki bilgileri arttırdığı ve çevre bilgisini geliştirdiği sonucuna ulaşılmıştır.

Araştırmanın bulgularında coğrafya dersindeki bitki coğrafyası kazanımlarının yeterli olmadığı görüşü, i̇lseven ve diğerlerinin (2017) yaptığı çalışmadaki coğrafya ve biyoloji derslerinde bitki coğrafyası konularını yeterli olmadığı görüşü ile paralellik göstermektedir.

Tarih öğretiminde Kırıkçı ve Yılmaz'ın (2017) belirttiği gibi tarihi çevrelerle tarih öğretiminin, öğrencilerde akademik başarı, bilgi ve çeşitli becerileri arttırdığı gerçeği, coğrafya eğitiminin de coğrafi çevreden ayrı düşünülemeyeceği, gençlerin doğal çevreyi ve bitkileri tanıyarak onları daha iyi koruyacağı gerçeğini ortaya koymaktadır.

Gelişen ve küreselleşen dünyada doğal çevre yok olmaya doğru yüz tutarken yerini betonlaşma almaya başlamıştır.

| Kastamonu Eğitim Dergisi, 27(5), 2019| 
Yok olan doğal çevrenin en önemli canlı unsurlarından biri olan bitkiler özellikle şehirlerde doğup büyüyen genç nesiller tarafindan çok az tanınmaktadır. Bu durum coğrafya dersi öğretim programında yer alan bitki coğrafyası ile ilgili kazanımların önemi bir kat daha artmaktadır.

\section{5. Öneriler}

Öğretmenler bitkiler ile ilgili kazanımları işler iken konunun daha iyi kavranması için öğrencilerin her birine "bir bitkiyi bahçede bizzat bitkinin yanında tanıtması projesi" verilmesi önerilmektedir.

Coğrafya ders kitaplarındaki bitki coğrafyası konularının geliştirilmesi, daha canlı ve daha çok çeşitte bitki türünün resimleri ile donatılması, bu konuya ilgiyi arttiracaktır.

Öğrenci merkezli eğitimde öğrencinin daha aktif olması hedeflendiğinden, öğrencilerin hazırlayacakları proje, performans ödevleri, video çekimleri gibi çalışmalara çevrelerinde buldukları bitki örneklerini, yaprak çeşitlerini de ekleyerek bu konudaki bilgilerini uygulamalı hale getirebilirler. Bitki koleksiyonlarının hazırlatıması ve sergilenmesi, değişik coğrafi kaynaklardan sınıflarda bir arşiv oluşturulması faydalı olacaktır.

Bitkilerin tamamını canlı olarak görmek onlara ulaşma zor olduğundan, bilgi teknolojilerinden faydalanarak bitki coğrafyası konusunun bütün dünyadan örnek bitki resimlerinin ve belgesellerinin sınıfta izletilmesi önemli yararlar sağlayacaktır.

Coğrafyanın yakından uzağa ilkesi göz önüne alınarak yakın çevremizden başlayarak bitkileri tanımak için geziler düzenlenmelidir. Gezilerde bitkilerin sosyal hayattaki kullanım alanlarının canlı olarak (marangoz atölyeleri, kâğıt ve mukavva fabrikaları, mobilya üretim tesisleri gibi.) gösterilmesi ile onların değeri öğrencilerin gözünde canlandırılmalıdır.

Bitki coğrafyası yükseköğretim coğrafya lisans programlarında önemli dersler arasındadır. Türkiye'deki Fen-Edebiyat Fakültesi coğrafya programı ile Eğitim Fakültesi coğrafya öğretmenliği programlarında bitki (vejetasyon) coğrafya derslerinin bir dönem boyunca işlenmesi konunun ehemmiyetini gözler önüne sermektedir. Ancak coğrafya öğretmen adayları tarafından öğrenilen bitki coğrafyası konuları ortaöğretim coğrafya öğretim programında sadece üç kazanım ile açıklanması, bu kadar önemli bir konuya yeterli önem ve zaman ayrılmadığını göstermektedir. Bu bakımdan bitki coğrafyası konusuna coğrafya öğretim programında daha fazla kazanım ile yer verilmesi önerilmektedir.

\section{Kaynakça}

Akman, Y., \& Ketenoğlu, O. (1987). Vejetsyon Ekolojisi (Bitki Sosyolojisi). Ankara: Ankara Üniversitesi Fen Fakültesi Yayın No:146.

Alım, M. (2008). Öğrencilerin Lise Coğrafya Programında Yer Alan Yeryuvarlağı ve Harita Bilgisi Ünitelerindeki Bazı Kavramları Anlama Düzeyleri ve Kavram Yanılgıları. Milli Eğitim Dergisi, sayı: 177, Ankara, 166-180.

Atalay, í. (1992). Genel Fiziki Coğrafya . İzmir: Ege Üniversitesi Basımevi.

Atalay, ì. (1994). Türkiye'de Vejetasyon Coğrafyası . İzmir: Ege Üniversitesi Basımevi.

Atalay, ì. (2013). Doğa Bilimleri Sözlüğü . İzmir: Meta Basım ve Matbaacılık. Genişletilmiş 2.Baskı.

Atayeter, Y. (2013). Bitki Coğrafyası. H. Akengin, \& I. Dölek içinde, Genel Fiziki Coğrafya (s. 265-282). Ankara: Pegem Akademi.

Aydınözü, D., \& Çoban, A. (2015). Bitki Coğrafyası Araştırma Yöntemleri. Marmara Coğrafya Dergisi Sayı: 31, - ISSN:1303-2429 E-ISSN 2147-7825 http://www.marmaracografya.com, 132-160.

Bilgili, M., \& Kocalar, A. O. (2014). Bazı Kavramlar Açısından Çevre ve Eğitiminin Değerlendirilmesi. Akademik Sosyal Araştırmalar Dergisi, Yıl: 2, Sayı: 7, Aralık sayısı, 461-471.

Çepni, S. (2014). Araştırma ve Proje Çalışmalarına Giriş. Trabzon: Celepler Yay.

Doğanay, H. (1993). Coğrafya'ya Giriş I. Ankara: Gazi Büro Kitabevi.

Doğanay, H. (2017). Coğrafya Ilim Alanları Sözlüğü. Ankara: Pegem Akademi Yayınları.

Frost, C. J. (2000). Comparing Attitudes About Forests Between Young Adults in North -Central Florida and The Peruvian Amazon. Florida-USA: Master thesis. University of Florida.

Geçit, Y. (2010). Coğrafya Eğitimi Alanında Temel Yönelimler. Kuram Uygulamada Eğitim Bilimleri 10 (2), 925-987.

Genç, H., Demirkaya, H., \& Karasakal, G. (2010). İlköğretim yedinci sınıf öğrencilerinin orman kavramını algılamaları: fenomegrafik bir araşttrma. Mehmet Akif Ersoy Üniversitesi Fen Bilimleri Enstitüsü Dergisi, 1, 34-48.

İlseven, S., Kasot, N., \& Illseven, G. (2017). Opinions of Education Administrators and Teachers on Vegetation Geography: Comparative Case Study. The Anthropologist 23:1-2, DOI: 10.1080/09720073.2016.11891942 ISSN: 0972-0073 (Print) (Online) Journal homepage: http://www.tandfonline.com/loi/ranp20, 199-208. 
Ince, Z. (2015). Ortaöğretim Coğrafya Dersi 10.Sınıf Müfredatının Yaşadığımız Çevreyi Tanımaya Katkısının Incelenmesi. Marmara Coğrafya Dergisi Sayı: 31, istanbul - ISSN:1303-2429 E-ISSN 2147-7825 http://www.marmaracografya.com, 330-344.

Karasar, N. (2013). Bilimsel Araştırma Yöntemi. Ankara: Nobel Akademik Yayıncılık, 25.Basım.

Kellert, S. R. (2007). Reflections on Children's Experience of Nature. Children and Nature Network C\&NN Leadership Writing Series 1(2).: https://www.childrenandnature.org/wp-content/uploads/2015/04/LWS_Vol1_02.pdf adresinden alındı

Kırıkçı, A. C., \& Yılmaz, K. (2017). Sosyal Bilgiler Öğretmen Adaylarının Tarihi Çevre Eğitimine Yönelik Görüşleri. Marmara Coğrafya Dergisi YII: Ocak $2017 \bullet$ SayI: $35 \bullet$ ISSN: 1303-2429 • E-ISSN: 2147-7825, 74-86.

MEB. (2011). Coğrafya Dersi Öğretim Programı (Revizyon TTKB:04/09/2014 tarih ve 85 sayılı karar). Milli Eğitim Bakanlığı Talim Terbiye Kurulu Başkanlığı.

MEB. (2018, 02 12). MEB Ortaöğretim Coğrafya Dersi Öğretim Programı 2018. MEB Öğretim Programlarını İzleme ve Değerlendirme Sistemi: http://mufredat.meb.gov.tr/ProgramDetay.aspx?PID=336 adresinden alındı

Memişoğlu, H., \& Öner, G. (2013). Sosyal Bilgiler Dersinde Öğrenci ve Öğretmen Görüşlerine Göre Coğrafya Konularının Öğretimi. Eğitim ve Öğretim Araştırmaları Dergisi 2013 Cilt:2 Sayı:3 Makale No:40 ISSN: 2146-9199, 347-366.

Merriam, S. B. (2009). Qualitative Research A Guide to Design and Implementation. San Francisco: Jossey Bass.

Özbaş, S. (2013). Ortaokul Öğrencilerinin Ormana Yönelik Tutumları: Lefkoşa Örneği. Sakarya University Journal of Education, 3/3 (Aralık /December 2013), 82-94.

Özey, R. (2002). Türkiye Coğrafyası ve Jeopolitiği. İstanbul: Aktif Yayınevi.

Sezer, A., \& Şanlı, C. (2017). Coğrafya Öğretim Programında ve Ders Kitaplarında Göç Olgusu. Marmara Coğrafya Dergisi, Sayı/ Issue: $36 \bullet$ ISSN: 1303-2429 • E-ISSN: 2147-7825, 16-25.

Şahin, V. (2015). İklim Değişimi ve Arıcılık Arasındaki Ilişkinin Öğrenci Görüşleri Açııından Değerlendirilmesi. Uluslararası Sosyal Araşttrmalar Dergisi Cilt: 8 Sayı: 40 Issn: 1307-9581 , 423-429.

Turna, i. (2017). Kent Ormancılığı. Karadeniz Teknik Üniversitesi: http://www.ktu.edu.tr/dosyalar/silvikultur_c858b.pdf adresinden alındı

Yıldıım, A., \& Şimşek, H. (2013). Sosyal Bilimlerde Nitel Araştırma Yöntemleri. Ankara: Seçkin Yayınclık Dokuzuncu Baskı. 